\title{
The relationship between marital quality, attitudes towards gender roles and life satisfaction among the married individuals
}

\author{
Semanur Kodan Çetinkaya* and Başaran Gençdoğan \\ Atatürk University, Turkey
}

(Received December 17, 2013; Accepted July 17, 2014)

\begin{abstract}
Society imposes different roles on women and men in the family and the society, concerning their gender. "Gender Role Concept" is very important in terms of the fact that it is related all parts of life of individuals, behaviors, perceptions and attitudes of men and women (Çelik, 2008). In this perspective, gender roles, which affect individuals' lives, cannot be isolated from the factors which affect marriage. In this context, the reflections of gender roles on marriage and also the effects of marriage, which is one of most important decisions of individuals, on quality of life were explored. For this purpose, the relationships between these three concepts were discussed. This research was a study of the relational model. The universe of this study included married individuals living in the province of Bayburt and Erzurum, and 639 individuals were participated to the research which was voluntary basis. The data were collected by using the "Marital Life Scale", "Gender Roles Attitudes Scale" and "Life Satisfaction Scale". These analyses were made on the data obtained from the study; t-test for independent groups, regression and correlation. According to study a positive and significant relationship was found between the marital quality, gender roles and the life satisfaction. There was found a significant differentiation; between the quality of the marriage and having children or family intervention; between the attitudes towards gender roles and gender, spouse's employment status or having children; between the life satisfaction and gender or spouse's employment status.
\end{abstract} Keywords: marital quality, attitudes towards gender roles, life satisfaction, married individual.

La relación entre calidad marital, actitudes hacia los roles de género y satisfacción de vida entre personas casadas

RESUMEN: La sociedad impone diferentes roles sociales a las mujeres y hombres en el seno familiar respecto a su género. El concepto de "roles de género" es muy importante dado que se relaciona con todas las partes de la vida, conductas, percepciones y actitudes de hombres y mujeres . En esta perspectiva, los roles de género, los cuales afectan a la vida de las personas, no pueden ser aislados de los factores que afectan el matrimonio. En este contexto, este artículo explora la reflexión sobre los roles de género en el matrimonio, como una de las decisiones más importantes de la persona, y también los efectos del matrimonio sobre la 
calidad de vida. Para este objetivo, las relaciones entre estos tres conceptos fueron discutidos. y se presenta un modelo relacional. En este estudio participaron voluntariamente 639 individuos casados que vivían en la provincial de Bayburt y Erzurum. Los datos fueron recogidos a través de la escala de vida marital, la escala de actitudes hacia los roles de género, y la escala de satisfacción con la vida. Para el análisis de los datos se realizaron pruebas t para grupos independientes, análisis de regresión y correlaciones. Los resultados indicaron una relación significativa y positiva entre la calidad marital, los roles de género y la satisfacción con la vida. Una diferencia significativa fue encontrada entre la calidad marital de acuerdo al criterio tener hijos y la intervención familiar, las actitudes hacia los roles de género basado en el género, el estatus del trabajo del cónyuge, tener hijos y la satisfacción con la vida basado en el género y el estatus laboral del cónyuge.

Palabras clave: calidad marital, actitudes hacia los roles de género, satisfacción con la vida, individuo casado.

\section{INTRODUCTION}

People may face many choices throughout their lives. One of these choices is the decision for prospective spouse. Spouse has an effect on individual's whole life including marital satisfaction and life satisfaction. Moreover, marital satisfaction can be related to the positive evaluation of any situation in their lives. Besides, there can be a lot of factors that related to marital satisfaction. One of these factors is gender roles which exist in a society. The concept of the gender has gained social framework, due to the view of masculinity and femininity. In this context, the concepts of "female" and "male," which express gender diversity, also influence individuals' behavior, attitudes, and lifestyles. In another words, individuals have gained their gender roles or identity through principles of the society (Arıc1, 2011).

Individuals reflect what they learn the roles within this socialization process into profession choice, domestic roles, to the all parts of life, in short. In other words, gender roles affect the individuals' way of life (Arıc1, 2011). In this sense, these developments might have influenced the family life, the quality of marriage and the life satisfaction.

As pointed out above, in all areas of life, society expects specific roles from men and women in terms of marriage. Marriage is principally an institution which constitutes generation, healthy interpersonal relationships and individual and social self-realization (Özgüven, 2009). Marriage is the union of two different persons who have different characteristics, who come to create a family as a part of a society, and they effort to retain this family (Kansiz \& Arkar, 2011). In this aspect, it can be stated that harmony between the individuals (wife and husband) is important for constituting a happy society (Polat, 2006). In this context, harmony between the two different persons is important to maintain a healthy marriage which is the source of happiness in the society and among the indivi- 
duals (Kansiz \& Arkar, 2011).

If we compare the East and the West in terms of, especially, institution of marriage, Turkey, which has been shaped by traditional values, seems to be more powerful than the Western societies. Nevertheless, recent studies show that there is increase not only in the rates of marriage but also rates of divorce in Turkey. Although the society perceives the words such as "widow" or "divorce" negatively, there is an increase in the number of divorced couples especially in the urban areas (Ersöz-Günindi, 1999).

At the second half of the twentieth century, divorce took the place of death as the cause of the termination of marriage. In the last quarter of the twentieth century, it is seen that one three of the divorces happened in the first seventh years of the marriage. And almost half of the divorces occurred in the first twentieth years of marriage. The rest of marriages are terminated by the death (Pinsof, 2002). The ratio of divorce in Turkey for the first five-years of married couples is $\% 38.3$ percent, more than 16 years married couples is $\% 24.8$ (TUIK, 2012). The increasing number of divorce and number of people who need for help in their problems about marriage in the whole world, force many researchers examine the quality of marriage with different variables (Şener \& Terzioğlu, 2002).

According to the literature about the quality of marriage, it can be stated that multiple concepts are used by the researchers. In the psychology literature; the marital relationship, marital satisfaction, marital happiness, marital stability, and marital adjustment are used in order to refer the marital quality. However, the researchers do not have consensus about how to define these concepts (Civan, 2011; Glenn, 1998; Norton, 1983; Spainer \& Lewis, 1980).

It can be seen that there are many researches about the quality of research conducted by international and Turkish academicians. The followings are the main topics which are investigated by researchers: marital quality and job satisfaction (Roger \& May, 2003; Tezer, 1992; Tezer, 1994), the legacy of parents' marital discord (Amato \& Booth, 2001), marital adjustment and their parental bonding (Çakır, 2008), marital adjustment, humor style and anxiety (Fidanoğlu, 2006), psychological well-being (Gove, Huge \& Style, 1983), perceptions of attachment style in midlife marriage (Hollist \& Miller, 2005), attribution (Berk, 2009), perfectionism (Koydemir, Selışık-Sun \& Tezer, 2005) gender roles and job satisfaction of married and working adults (Anar, 2011), marital satisfaction and life satisfaction (Çelik \& Tümkaya, 2012).The changing gender roles can also be considered as one of the factors which affect marital life.

Gender roles also comprise the gender stereotypes about men and women. For instance, while in traditional societies men are more valuable than women and men should establish sovereignty over women, according to the modern societies, men and women should be equal in every part of life (Best \& Williams, 1996; Burr, 1999). Moreover, while in traditional societies married women are depended on her husband, in recent years there is some changes in this area (Connell, 1998). The growing rate of sharing households between husband and wife, and increasing of number of working women in the society has changed the 
gender roles (Best \& Williams, 1996). As a result, the change of the roles of women when they enter into the business life causes them to set a balance between home and job (Bussey \& Bandura, 2004). Also, rapid developments cause the certain changes in the family and the gender roles (Özgüven, 2009).

As a result, changing gender roles are likely to affect the family. In terms of the marital life, it can be seen that the husband-wife relationships is established on the basis of tasks and responsibilities. For example, while men are responsible for bringing money to home, women are responsible for motherhood, childcare and household etc (Dedeoğlu, 2009). However, with increasing rate of women in business and education areas, the gender roles have changed. And this created the image of "new women" which refers to women who have jobs which are not related to home. Changing the role of women in the society also pushes change the social roles. Nowadays, woman's place is not only at home, women also are in social and professional environment. So, with the concept of modern women, new duties have emerged such as sharing household between husband and wife (Connell, 1998). Changing roles of women and men, and misunderstanding of these roles can lead to conflict between the spouses. The quality of marriage between spouses depends on the accepting of changing gender roles (Özgüven, 2009).

Therefore, it can be stated that it will be significant to recognize the current position of the gender roles and how it was perceived, in terms of its influence on marriage relationship (Kadılar, 2011).

The other factor which has influence on marriage is the life satisfaction (Çelik \& Tümkaya, 2012). In this regard, it can be express that the marriage, which is one of the most important experiences of human life, affects the quality of life (Hünler \& Gençöz, 2003). According to Sekaran (1983), life satisfaction includes two important concepts, namely marriage and job satisfaction, and it leads a good job and a happy family.

There are certain responsibilities that community bears on adults. One of them is creating a family and obtaining a job. In this context, individuals spend majority of their time by working and remaining time with their families. Therefore, it is important for individuals to have satisfying marriage in terms of maintaining a happy life (Anar, 2011). Another concept, which influences individuals' marital satisfaction and life satisfaction, is "gender roles." Hence, this study is important in terms of showing the relationship between these three concepts.

Individuals' behaviors and attitudes are shaped according to direction of gender perspective, since birth. The first place that this view point is gained is family. With this perspective, individuals learn gender roles as men and women. There are a lot of factors that affect the formation and conveying the gender roles. Some of these factors are gender, family, work life, family type, and so on. It is important to know these factors that affect gender roles. Understanding the gender roles is important in terms of perceiving the effects of gender roles on individuals and how it turns into conflict situation.

In the process of learning the gender roles, the treatments that individuals ex- 
perience in terms of their gender, cause a determined perception of individuals. In this context, gender is taken as a variable, as an important concept in terms of gender roles. The gender variable is also taken in terms of being one of the most important factors in the process of the formation of gender roles. In addition, family is also important, which is the first place where learning of gender roles occurs (Akgül-Gök, 2013). Firstly, the research was conducted on married individuals, in terms of learning how the gender roles, which are taught by parents, reflect on marriage and quality of life.

Moreover, it seen that when women gain rights in workplace, flexibility occurred also in gender roles. In this context, spouse's occupation status is taken as a variable in terms of articulating how having employed and unemployed spouse effective and how it effects on marriage satisfaction and life quality. How the changing roles influence the marital satisfaction? In Turkey, the close relatives of bride and groom can easily interfere family relationships. This fact limits the freedom of married individuals in terms of decision-making and action. According to the studies, around $24 \%$ of divorces occur due to discord between married couples and their families. Therefore, respect for elders should be kept, which is one of the imperatives of the society and the culture, yet couples should solve their problems without letting others to intervene it (Özgüven, 2001). However, the change in the gender roles is reducing the possibility of external intervention. In this study, it is aimed to explore the influence of individuals on life and marital satisfaction by taking this variable. Children, which are a fruit of marriage, also affect marital satisfaction of individuals. In this context, having children is taken as a variable.

It is also important to uncover factors that determine gender roles, rather than identifying individuals as traditionalist or egalitarian, in terms of letting individuals to determine their life by realizing their potentials. The fact that family is the first place that the social process is determined and learnt and how it reflects on individuals' marriage quality and how it affects their life satisfaction has gained importance (Aric1 and Bilge, 2011). This study was intended to articulate which factors affect gender roles and how they affect life satisfaction and quality of marriage of individuals. Although studies are undertaken about the relationship between the gender roles and marital satisfaction, they are not at the desired level. More research is needed on this issue.

In conclusion, how to perceive men and women about their gender roles and how to share those roles between husband and wife is important in order to know how it affect the life satisfaction and marital satisfaction (Ersöz-Günindi, 1999). In other words, there are so many studies made about how the difference between men and women influence their marital satisfaction, life satisfaction and job satisfaction. In the literature, there are many researches about gender roles attitudes, quality of marriage and life satisfaction with various variables, however there is not any study which examines the relationships between these three concepts. And so, it is considered that this paper would contribute to the field, especially in the area of marital counseling. Another goal of the study is to exa- 
mine the relationship between gender roles attitudes, life satisfaction and quality of marriage, in terms of demographic variables (gender, age, number of children, duration of marriage etc.).

\section{MATERIALS AND METHODS}

\section{Population and Sampling}

The sample of the study is formed of 639 married individuals who are living in Erzurum or Bayburt city center in Turkey. The sample of the study is chosen randomly and unproportionally out of the population.

Demographic Information is give at Table 1.

\section{Table 1. Demographic Information}

\begin{tabular}{|c|c|c|c|}
\hline Personal Information & & $\mathrm{N}$ & $\%$ \\
\hline \multirow{2}{*}{ Gender } & Female & 325 & 51.3 \\
\hline & Male & 308 & 48.7 \\
\hline \multirow{4}{*}{ Age } & 20-30 age & 184 & 28.8 \\
\hline & $31-41$ age & 300 & 47.0 \\
\hline & $42-52$ age & 115 & 18.0 \\
\hline & 52 age and over & 39 & 6.1 \\
\hline \multirow{2}{*}{ Spouse's occupation status } & Yes & 435 & 68.2 \\
\hline & No & 203 & 31.8 \\
\hline \multirow{2}{*}{ Having at least a child } & Yes & 510 & 80.1 \\
\hline & No & 127 & 19.9 \\
\hline \multirow{2}{*}{ Intervention of family relatives } & Yes & 72 & 11.5 \\
\hline & No & 556 & 88.5 \\
\hline
\end{tabular}

According to the research $51.3 \%$ of respondents were female and $48.7 \%$ were male; $28.8 \%$ of respondents were between $20-30$ years old and $47.0 \%$ were between $31-41$ years old, $18 \%$ were $42-52$ years old, and $6.1 \%$ were 52 and over years old. Moreover, $68.2 \%$ of respondents' spouses have a job, $31.8 \%$ of respondents' spouse do not have a job; $80.1 \%$ of respondents have at least a child, $19.9 \%$ of them do not have a child; $11.5 \%$ of respondents have responded "yes" 
to the question about intervention of family relatives, $88.5 \%$ said "no."

\section{Data Collection}

\section{Gender Roles Attitudes Scale}

Gender roles attitude scale was developed by Zeyneloğlu and Terzioğlu (2011). The gender roles attitude scale (GRAS) contains 38 items and 5 subdimensions (egalitarian gender roles, female gender roles, marriage gender roles, traditional gender roles and male gender roles). The scale's construct validity is dealt by item analysis and factor analysis with rotation. Statistically significant differences were determined among all survey items $(\mathrm{p}<.01)$. The scale's Cronbach alfa reliability coefficient for 38 items was found to be .92 . Gender roles attitude scales reliability was confirmed by internal consistency. It was found that reliability factor is .80 for female gender roles, .78 for egalitarian roles, marriage gender roles, traditional gender roles, .72 for male gender roles. The Pearson correlation coefficients were .65 and .35 for all sub-scales, respectively. This result shows that the scale and its subscales are reliable. Therefore, the findings showed that the survey is a valid and reliable scale to determine university students' attitude towards gender roles.

Gender roles attitude scale was a 5 point likert type scale. The scale were scored as 5 points for 'completely agree', 4 points for 'agree', 3 points for 'undecided', 2 points for 'disagree', and 5 points for 'absolutely disagree'. The highest possible score from the scale was 190 and the lowest score was 38. The higher scores from scale showed that the students had more egalitarian attitudes towards gender roles and the lower score showed that the students' attitudes were more traditional (Zeyneloğlu \& Terzioğlu, 2011).

The internal consistency coefficient .90 was found by researchers. In the work that is done on married individuals.

The Satisfaction with Life Scale (SWLS; Deiner, Emmons, Larsen \& Griffen, 1985)

The inventory was adapted to Turkish by Yetim (1993). The scale is formed of 5 items on a 7 points likert scale. The highest possible score from the scale was 35 and the lowest 5 . Higher score expresses higher life satisfaction. Test reliability was found .86, test-retest reliability was found .73 (Yetim, 2003).

\section{Marital Life Satisfaction}

Marital life scale is a five point likert type of scale. It is consists of 10 items such as "Most of the things that I expect from marriage was realized", and "I think our marriage is very meaningful". The scale were scored as 1 points for 'absolutely disagree', 2 points for 'disagree', 3 points for 'undecided', 4 points 
for 'agree' and 5 points for 'completely agree'. The highest possible score from the scale was 50, and the lowest was 10 . A higher score indicating greater marital satisfaction. Test-retest reliability of scale was found .85, and the internal consistency of the scale was .91 as estimated by Cronbach's coefficient alpha (Tezer, 1996).

\section{Demographic Information Form}

Demographic Information Form was prepared by the researcher to get information about socio-demographic characteristic of the participants. The form was constructed with close-ended questions (e.g., what is your spouse's education level?). In the form, socio-demographic measures age, gender, occupation, having children, family intervention were questioned by the participants

\section{Collecting and Analyzing the Data}

The data were collected from the married individuals directly. SPSS packaged software was used for statistical analysis of data, correlation, regression and t-test for independent group were applied. And standard deviations, intercorrelations, and internal consistency of efficient of variables were used.

\section{RESULTS}

\section{Correlations among the Variables}

As can be seen in Table 2, marital quality significantly and positively correlated with gender roles attitudes $(r=.12, p<.01)$ and life satisfaction $(r=.34, p<.01)$.

Table 2. Correlations among the Measures of Study

\begin{tabular}{lccc}
\hline & $\begin{array}{c}\text { Gender Roles } \\
\text { Attitudes }\end{array}$ & Life Satisfaction $\begin{array}{c}\text { Marital } \\
\text { Quality }\end{array}$ \\
\hline 1. Gender Roles Attitudes & 1 & & \\
& & & \\
2. Life Satisfaction & 626 & 1 & \\
& .073 & 618 & \\
3.Marital Quality & .073 & .344 & 1 \\
& 609 & .000 & 626 \\
\hline
\end{tabular}

Multiple Regression Analysis

By using multiple regression analysis, each step of independent variables was assessed by referring to what degree they statistically contributed to the multiple 
regression equation. Multiple regression analysis has applied to determine which dimensions were the best predictors of marital quality. Table 3 shows the results of multiple regression analysis.

Table 3. Multiple Regression Analysis Predicting Marital Quality

\begin{tabular}{lccccc}
\hline Variables & $\mathrm{B}$ & $\begin{array}{c}\text { Standart } \\
\text { Error of } \mathrm{B}_{\mathrm{B}}\end{array}$ & $\mathrm{B}$ & $\mathrm{t}$ & $\mathrm{p}$ \\
\hline Constant & 27.933 & 1.998 & & 13.978 & .000 \\
Gender roles attitudes & .035 & .014 & .099 & 2.547 & .011 \\
Life satisfaction & .306 & .035 & .338 & 8.677 & .000 \\
\hline $\mathrm{R}=0.359$ & $\mathrm{R}^{2}=0.13$ & & & & \\
$\mathrm{~F}_{(2.578)}=42.721$ & $\mathrm{p}=.000$ & & & & \\
\hline
\end{tabular}

As seen in Table 3, gender roles attitudes and life satisfaction is the predictors of marital quality and they accounted for $13 \%$ of the variance. According to standardized beta coefficient indicated that relative importance of predictor variables; life satisfaction $(\beta=.35, \mathrm{p}=.05)$ and gender roles attitudes $(\beta=.14, \mathrm{p}=.05)$.

Findings and Interpretations Regarding Gender Roles Attitudes, Life Satisfaction and Marital Quality Scores of Married Individuals in terms of Their Gender

$\mathrm{t}$ value, standart deviation and mean values of gender role attitudes, life satisfaction and marital quality scores according to gender variable are given in Table 4 below.

Table 4. Multiple Regression Analysis Predicting Marital Quality

\begin{tabular}{|c|c|c|c|c|}
\hline & & $\begin{array}{c}\text { Gender roles } \\
\text { attitudes }\end{array}$ & Life satisfaction & Marital Quality \\
\hline & & $\mathrm{X} \pm \mathrm{S} . \mathrm{s}$ & $\mathrm{X} \pm \mathrm{S} . \mathrm{s}$ & $\mathrm{X} \pm \mathrm{S} . \mathrm{s}$ \\
\hline \multirow{3}{*}{ Gender } & Female & $145.81 \pm 15.97$ & $25.32 \pm 6.74$ & $40.40 \pm 6.09$ \\
\hline & Male & $125.30 \pm 17.05$ & $23.55 \pm 7.10$ & $39.89 \pm 6.28$ \\
\hline & TEST & $\begin{array}{l}t=15.47 \\
p=.000\end{array}$ & $\begin{array}{c}\mathrm{t}=3.2 \\
\mathrm{p}=.002\end{array}$ & $\begin{array}{l}\mathrm{t}=1.04 \\
\mathrm{p}=.297\end{array}$ \\
\hline \multirow{3}{*}{$\begin{array}{l}\text { Occupation } \\
\text { Status }\end{array}$} & Employed & $141.68 \pm 17.12$ & $24.93 \pm 6.71$ & $40.24 \pm 6.15$ \\
\hline & Unemployed & $123.28 \pm 18.15$ & $23.44 \pm 7.36$ & $39.93 \pm 6.23$ \\
\hline & TEST & $\begin{array}{l}\mathrm{t}=12.24 \\
\mathrm{p}=.000\end{array}$ & $\begin{array}{l}\mathrm{t}=2.48 \\
\mathrm{p}=.013\end{array}$ & $\begin{array}{c}\mathrm{t}=.57 \\
\mathrm{p}=.568\end{array}$ \\
\hline \multirow{3}{*}{ Having Child } & Yes & $134.53 \pm 19.32$ & $24.31 \pm 7.03$ & $39.68 \pm 6.04$ \\
\hline & No & $141.23 \pm 19.03$ & $25.04 \pm 6.61$ & $41.92 \pm 6.35$ \\
\hline & TEST & $\begin{array}{l}\mathrm{t}=3.49 \\
\mathrm{p}=.001\end{array}$ & $\begin{array}{l}\mathrm{t}=-1.05 \\
\mathrm{p}=.293\end{array}$ & $\begin{array}{l}\mathrm{t}=-3.68 \\
\mathrm{p}=.000\end{array}$ \\
\hline
\end{tabular}




\begin{tabular}{ccccc}
\hline \multirow{2}{*}{\begin{tabular}{c} 
Interventon of $\begin{array}{c}\text { Yes } \\
\text { family } \\
\text { relatives }\end{array}$ \\
\cline { 2 - 5 }
\end{tabular}} & No & $139.02 \pm 20.50$ & $24.21 \pm 6.23$ & $37.25 \pm 6.76$ \\
\cline { 2 - 5 } & \multirow{2}{*}{ TEST } & $135.66 \pm 18.99$ & $24.56 \pm 7.07$ & $40.51 \pm 5.60$ \\
\hline & & $\mathrm{t}=1.392$ & $\mathrm{t}=-.401$ & $\mathrm{t}=-4.273$ \\
$\mathrm{p}=.164$ & $\mathrm{p}=.689$ & $\mathrm{p}=.000$ \\
\hline
\end{tabular}

As seen in the Table 4, there is significant differences between gender roles attitudes and life satisfaction scores of female and male individuals in favor of female students $\left(\mathrm{t}_{(618)}=15.47, \mathrm{p}=.000 ; \mathrm{t}_{(610)}=3.2, \mathrm{p}=.002\right)$. However there is found no significant differences between marital quality scores of female and male $\left(\mathrm{t}_{(619)}=1.04, \mathrm{p}=.297\right)$.

Findings and Interpretations Regarding Gender Roles Attitudes, Life Satisfaction and Marital Quality Scores of Married Individuals in terms of OccupationStatus

$\mathrm{t}$ value, standart deviation and mean values of gender role attitudes, life satisfaction and marital quality scores according to occupation status variable are given in Table 4 above.

As seen in Table 4, there is a significant difference between gender roles attitudes and life satisfaction scores of regarding to their spouse's occupation status in the favor of employed individuals $(\mathrm{t}(623)=12.24, \mathrm{p}=.000 ; \mathrm{t}(615)=2.48, \mathrm{p}=$ .013). However, there is found no significant differences between marital quality scores of regarding to their spouse's occupation status $(\mathrm{t}(623)=.57, \mathrm{p}=.568)$. According to general evaluation of the finding, it can be asserted that gender roles attitudes and life satisfaction scores of married individuals whose spouses have a job are higher than married individuals whose spouses do not have a job.

Findings and Interpretations Regarding Gender Roles Attitudes, Life Satisfaction and Marital Quality Scores of Married Individuals in term of having a Child

$\mathrm{t}$ value, standart deviation and mean values of gender role attitudes, life satisfaction and marital quality scores according to having a child variable are given in Table 4 above.

As seen in the Table 4, there is significant differences between gender roles attitudes and marital quality scores regarding to have children compared to individuals who do not have children $\left(\mathrm{t}_{(622)}=3.49, \mathrm{p}=.001 ; \mathrm{t}_{(622)}=-3.68, \mathrm{p}=.000\right)$. However there is found no significant differences between life satisfaction scores of individuals who have or don't have $\left(\mathrm{t}_{(614)}=-1.05, \mathrm{p}=.293\right)$. Considering overall evaluation, it can be stated that scores of gender role attitudes and marital quality of individuals who don't have children are significantly higher than individuals who have. This finding can be explained by the fact that majority of the sample have at least a child. Besides, this finding might be concluded by that having 
children increases the responsibilities they confront in marital life.

Findings and Interpretations Regarding Gender Roles Attitudes, Life Satisfaction and Marital Quality Scores of Married Individuals in terms of Intervention of Family Relatives

$\mathrm{t}$ value, standart deviation and mean values of gender role attitudes, life satisfaction and marital quality scores according to intervention of family relatives are given in Table 4 above:

As seen in the Table 4, there is found significant differences between marital quality scores and individuals who say no in the favor of intervention of family relatives $\left(\mathrm{t}_{(615)}=-4.273, \mathrm{p}=.000\right)$. However there is found no significant differences between gender roles attitudes and life satisfaction scores of individuals who say yes or no $\left(\mathrm{t}_{(613)}=1.392, \mathrm{p}=.164 ; \mathrm{t}_{(607)}=.401, \mathrm{p}=.689\right)$. According to general evaluation, it can be maintained that scores of marital quality of individuals who say no are significantly higher than individuals who say yes.

\section{DISCUSSION}

This study has examined the relationship between gender roles attitudes, life satisfaction and marital quality. It was supposed that gender roles attitudes and life satisfaction would be associated positively to marital quality. In the literature, most of the studies about the relation of gender roles and marital satisfaction used "Bem sex role" scale and the result of the studies found a positive relationship between gender roles and marital satisfaction(Aida and Fabo, 1991; Anar, 2011; Çınar, 2008). Based on research conducted, it was considered that gender roles may be related to quality of marriage and the results were in the expected direction. This research's result that there is a meaning relationship between the quality of marriage and gender roles is also supported by the results of the study conducted by Aida and Fabo (1991). Their research show that couples who have egalitarian role have significantly higher marital satisfaction than couples who have traditional roles.

Moreover, one of the important findings of this paper is that there is a significant relationship between marital satisfaction and life satisfaction, which is also supported by some previous researches (Nehir et al., 2009 \& Ng et al., 2009). Sekaran's (1983) statements, that marital satisfaction and job satisfaction are the two significant determinants of the life satisfaction also support this fact.

In this context, it can be said that life satisfaction is one of the most important factors affecting the marriage. In a study conducted by Lykken and Tellegen (1996), it is also found that marital status affects life satisfaction. In this respect, the relationship between marital satisfaction and life satisfaction cannot be ignored. In addition, as a result of the study made by Çelik and Tümkaya (2012) it is found that there is a meaningful relationship between the quality of marriage and life satisfaction, which also supports the conclusion of this research. 
The results of the analysis confirm the hypothesis and the importance of the gender roles attitudes and life satisfaction. Moreover, regarding multiple lineer regression analysis, gender roles attitudes and life satisfaction as the predictors of marital quality and they accounted for $13 \%$ of the variance. There could be many other factors which influence the marital quality (Güven and Sevim, 2007). There are many studies which examine the factors affecting marital satisfaction. Followings are some of the factors: Marital satisfaction and intimacy have meaningful and positive relationship (Goodman, 1999), women who look for equity in sharing home works have higher marital satisfaction (Hasta, 1996; Steven, Kiger and Riley), similarity in mariage and family of origin relationship have significantly predicted marital satisfaction (Cihan-Güngör, 2007), marital satisfaction and emotional intelligence have meaningful and positive relationship (Üncü, 2007), increase of marital conflict scores (Şendil and Korkut, 2012), and having children causes decrease the marital satisfaction (Şendil and Korkut, 2012; Twenge, Campel and Foster, 2003 ), and some studies show that women consider work as getting rid of the responsibilities of house works which increase marital satisfaction (Tezer, 1994). In this context, one may mention many factors that affect marital quality.

Furthermore, significant difference is found between gender roles attitudes and life satisfaction scores of male and female married individuals in favor of female. There is found no significant difference between marital quality and gender. As to the overall evaluation of the findings, it can be said that female individuals' gender role attitudes are significantly higher than male individuals' scores. That is, regarding to results, female individuals have more egalitarian role attitudes compared to male. This finding can be explained by that social influence is stronger on male gender roles attitudes, and women have a strong desire to change their positions including family and work life in a society $\mathrm{Ku}-$ lik, 1999). In addition, it can be explained with the fact that women more quickly adapt than men and take more positive stances, in terms of gender roles (Scott et al, 1996, reported: O'Sullivan, 2012). Moreover, this finding can be supported by researchers of Kulik (1999) and Zeyneloğlu (2008).

As a result of the finding, it can also be stated that female individuals' life satisfaction scores are significantly higher than male individuals' scores. This finding can be clarified by that men have more responsibilities to society. Moreover, Kirtıl (2009) has found same result in her research and explained this situation with social skills. That means, women have more social skills to able to express their feeling and establish more close relationships. Having low life satisfaction among men can be explained by the fact that they perceive themselves as the assurance of family and therefore they have anxiety to find job. Although this finding can be supported by Cenkseven and Akbaş (2007), Dost-Tuzgöl (2007), Dikmen (1995), Ulucan et al. (2011), can't be supported by Giusta, Jewell and Kambhampati (2011), Gündoğar et al. (2007), Özgür, Gümüş-Babacan and Durdu (2010), Ng et al. (2009), Selçukoğlu (2001). The different results in studies may be because of the fact that effects of gender change according to the struc- 
ture of a society or a research group (Çivitci, 2009).

In the result of the research, there is found no meaningful difference between the gender and quality of marriage. This finding parallels with the findings of Çınar (2008), Günay (2007), Güven (2005); yet does not parallel with findings of Allendorf and Ghimire (2012), Anar (2011), Çakır (2008); Ng et al (2008). This situation can be explained with the fact that assessment of quality of marriage does not change in terms of gender.

There is found significant difference between gender roles attitudes and life satisfaction scores of married individuals in the favor of whose spouse has a job. However, there is found no significant differences between marital quality and occupation status. According general evaluation of the findings, it can be stated that gender roles attitudes scores of individuals whose spouses are employed are higher than others. This finding can be related to the awareness of the opportunity of being employed and having equal rights in their jobs between the two genders. At the same, this can be explained by the fact that change of worldview with work life (Alisbah-Tuskan, t.y) and in the family which woman works, couples adopt more positive attitude (İmamoğlu, 2012).

West and Pilgrim (2010) found in the research that employed women experienced less isolation and more equal gender relations with their husbands in respect to the other women. Also for some women, working in a job seems to be reflection of less conservative gender roles attitudes (Baluja Flagstad, 2003). These statements can be considered as supportive arguments of the research.

Moreover, according to the finding, it can be stated that life satisfaction scores of individuals whose spouses are employed are higher than others. This can be explained by that individuals feel more valuable when they earn money. Çakır (2008) has shown that individuals whose spouses are employed are observed having higher life satisfaction. Therefore, this finding of research supports the research.

There is found significant difference between gender roles attitudes and marital quality scores of married individuals in the favor of who don't have a child. However, there is found no significant differences between life satisfaction and having a child or not. According to general evaluation of the finding, it can be stated that gender roles attitudes and marital quality of married individuals who do not have a child are higher than married individuals who have a child. A number of previous studies showed that childless individuals have a more marital adjustment than do individuals who have a child (Houseknecht, 1979; Renne, 1970 \& Ryder, 1973). These can be explained that childless couples have more time to develop their relationship and resources to devote their marriage, so they are better adjusted than people with children. On the other hand, a research about individuals who have child shows that if the number of the children increases, women's satisfaction about their marriages also increases (Houseknecht \& Macke, 1981).

Angeles (2009) states that there would be certain positive relationship between having children and life satisfaction. According to Angeles (2009) previous 
studies failed to find out this positive effect since they did not take into consideration of married couples. However, even though this paper examines married couples, there is found no positive relationship between having children and life satisfaction which supports the general literature.

There is found significant difference between marital quality and intervention of the relatives in favor of married individuals who say no. However there is found no gender role attitudes, life satisfaction and intervention of the relatives. Considering this finding, it can be assumed that marital quality scores of individuals who say no are higher than the scores of individuals who say yes. That is, individuals who do not think their relatives or other people to intervene their marriage have higher marital quality than individuals who say yes. This finding can be explained by gender roles that affect the relative status of family members. Status of family members and roles influence the decision and accessing to the resources (Houseknecht, 1979). Also, this finding can be explained by perceptions of individuals about relative intervention. Especially, in Turkey, children are grown dependent on their families, so when children get married they do not want to leave their family. This situation prevents them to live independently from their family in Turkey (Özgüven, 2001). There were no studies in the literature dealing with intervention of relatives to married individuals. The reason this case is not investigated in Turkey, this case in might be due to fact that it is well adjusted by the community.

It would be helpful to state that this study has a number of limitations; firstly, the sample of this study is limited to married individuals who are living center cities of Bayburt and Erzurum, in Turkey. And so, it is questionable to generalize different individuals who are living different city. For generalization of the findings to the community, different regions and localities should also be considered.

Secondly, this research is limited by the use of gender role attitudes, life satisfaction and marital quality scale. And any qualitative measure was not used. Despite of these limitations, this research provides important information about the gender roles attitudes, life satisfaction and marital quality.

\section{RECOMMENDATIONS}

As a result of the research, it can be stated that men are more traditional than women, so institutions should organize some programs especially for men. It can be useful to establish marriage counseling centers for individuals who have some problems about their marriages. With the framework of the study, conferences can be organized in order to increase the awareness of individuals about marriage and preparation for wedding. Similar studies can be made to wider sample groups considering much more different variables.Egalitarian approach should be taught to everyone starting from the childhood by providing egalitarian training programs.

Furthermore, future researches can be beneficial for the field in order to deter- 
mine the gender roles attitudes, marital quality and life satisfaction.

Lastly, the present study is limited to married men and women only. Therefore, the result may not apply to divorced, widowed, or single men and women who have interpret social structure different. Exploration in this direction is needed in future research.

\section{ACKNOWLEDGEMENTS}

This article is the summary of a part of my unpublished Masters' thesis that is completed at the Ataturk University, Turkey and is titled "Investigation of the Relationship between Marital Quality, Attitudes towards Gender Roles and Life Satisfaction among the Married Individuals."

\section{REFERENCES}

Aida, Y. \& Falbo, T. (1991).Relationships between marital satisfaction, resources, and power strategies.Sex Roles, 24(1/2), 43-55.

Akgül-Gök, F. (2013).Evli kadın ve erkeklerin toplumsal cinsiyet rolleriyle ilgili algılarının aile işlevlerine yansıması. M.A.Thesis. Ankara: Hacettepe University.

Alisbah-Tuskan, A. (n.d). Toplumsal cinsiyet ve toplumda kadına biçilen roller ve çözümleri.445-449. Avalaible on http://portal.ubap.org.tr/App_Themes/ Dergi/2012-99-1179.pdf. Accessed on 20.04. 2012.

Allendorf, K. \& Ghimire, D. J. (2012).Determinant of marital quality in an arranged marriage society.Social Science Research, 42, 59-70.

Amato, P. R. \& Booth, A. (2001). The legacy of parents' marital discord: consequences for children's marital quality. Journal of Personality and Social Psychology, 81(4), 627-638, doi: 10.1037/0022-3514.81.4.627.

Anar, B. (2011). Evli ve çalışan yetişkinlerin toplumsal cinsiyet rolleri ile evlilik doyumu ve iş doyumu ilişkisinin incelenmesi. M.A.Thesis. Adana: Çukurova University.

Angeles, L. (2009). Children and life satisfaction.Journal of Happiness Studies.11(4), 523-538.

Arıc1, F. (2011).Üniversite öğrencilerinde toplumsal cinsiyet rollerine ilişkin algilar ve psikolojik iyi oluş. M.A.Thesis. Ankara: Hacettepe University.

Arıc1, F. \& Bilge, F. (2011). Toplumsal Cinsiyet Oluşumu Ölçeği’nin (TCOÖ) Türk kültürüne uyarlanması. XI. National Psychological Counseling and Guidance Congress, 3-5 October, İzmir.

Baluja-Flagstad, K. (2003). Gender roles at home and abroad: the adaptation of Bangledeshi immigrants. Newyork: LBF Scholarly Publishing LLC.

Berk, M. (2009).Evli öğretmenlerin yükleme tarzları ve evlilik doyum algılarının bazı demografik değişkenler açısından incelenmesi.M.A.Thesis. Adana: Çukurova University.

Best, D. \& Williams, J. (1996).Sex, gender and culture.Berry, J.W., Segall, M.H. 
and Kağıtçıbaş1, Ç. (Eds.), Hands book of cross-culturel psychology social behavior and applications (Second edition), (pp. 163-213).

Burr, V. (1999). Gender and social psychology.Newyork: Routladge.

Bussey, K. \& Bandura, A. (2004).Social cognitive theory of gender development and functioning.In A.H.Eagly, A.E.Beall and R.J. Sternberg (Eds), The psychology of gender, (pp. 92-120). New York: The Guilford Press.

Çakır, S. (2008).Evli bireylerin evlilik uyumlarının ana-babalarına bağlanma düzeyleri ve demografik değişkenler açısından incelenmesi.M.A.Thesis. İstanbul: Marmara University.

Çelik, Ö. (2008). Ataerkil sistem bağlamında toplumsal cinsiyet ve cinsiyet rollerinin benimsenmesi.M.A.Thesis. Ankara: Gazi University.

Çelik, M. \& Tümkaya, S. (2012). Öğretim elemanlarının evlilik uyumu ve yaşam doyumlarının iş değişkenleri ile ilişkisi. Ahi Evran Üniversitesi Kırşehir Eğitim Fakültesi Dergisi (KEFAD), 13(1), 223-238.

Cenkseven, F. \& Akbaş, T. (2007).Üniversite öğrencilerinde öznel ve psikolojik iyi olmanın yordayıcılarının incelenmesi.Türk Psikolojik Danışma ve Rehberlik Dergisi, 3(27), 43-65.

Çınar, L. (2008). Evlilik doyumu: cinsiyet rolleri ve yardım arama tutumu. M.A.Thesis. Ankara: Gazi University.

Cihan-Güngör, H. (2007). Evlilik doyumunu açıklamaya yönelik bir model geliştirme.M.A. dissertation. Ankara: Gazi University.

Civan, A. (2011). Eşlerin duygu dışavurum tarzları ile algılanan evlilik kalitesinin ilişkisi ve duygusal farkındalığın rolü.M.A.Thesis. Mersin: Mersin University.

Çivitçi, A. (2009). İlköğretim öğrencilerinde yaşam doyumu; Bazı kişisel bilgiler ve ailesel özelliklerin rolü.Eğitim Fakültesi Dergisi ,XXII(1), 29-52.

Connell, R. W. (1998). Toplumsal cinsiyet ve iktidar.(Çev. C. Soydemir). İstanbul: Ayrıntı Yayınları.

Dedeoğlu, S. (2009).Toplumsal cinsiyet rolleri açısından Türkiye'de aile ve kadın emeği.Toplum ve Bilim Dergisi, 86, 139-170.

Dikmen, A. A. (1995). Kamu çalışanlarında iş doyumu ve yaşam doyumu. M.A.Thesis. Ankara: Ankara University.

Dost-Tuzgöl, M. (2007).Üniversite öğrencilerinin yaşam doyumunun bazı değişkenlere göre incelenmesi.Pamukkale Üniversitesi Eğitim Fakültesi Dergisi, 2(22), 133.

Ersöz-Günindi, A. (1999). Cinsiyet rollerine ilişkin beklenti, tutum, davranışlar ve eşler arası sorumluluk paylaşımı (kamuda çalışan yönetici kadınlar örneği). Ankara: T.C. Kültür Bakanlığı Yayınları.

Fidanoğlu, O. (2006). Evlilik uyumu, mizah tarzı ve kaygı düzeyi arasındaki ilişki.M.A.Thesis. İstanbul: Marmara University.

Giusta, M. D., Jewell S.L., \& Kambhampati, U. (2011).Gender and life satisfaction in the UK.Feminist Economics, 17(3), 1-34.

Glenn, N. D. (1998). The course of marital success and failure in five American 10 year marriage cohorts.Journal of Marriage and Family, 60, 569-576. 
Goodman, C. (1999). İntimacy and autonomy in long term marriage. Journal of Gerontological Social Work. 32, 83-97.

Gove, W. R., Hughes, M., \& Style, C. B. (1983). Does marriage have positive effects on the psychological well-being of the individual?.Journal of Health and Social Behavior, 24(2), 122-131. http://www.jstor.org/stable/2136639 accessed on 28.06.2012.

Günay, S. (2007). Evlilik Çatışması, Nedensellik-Sorumluluk Yüklemeleri, Eşlerin Evlilik İlişkisinden Sağladıkları Genel Doyuma İlişkin Görüşleri ve Evliliğe İlişkin Değerlendirmeler Arasındaki İlişkiler. Ankara.Unpublished M.A.Thesis. Ankara: Ankara University.

Gündoğar, D., Gül-Sallan, S., Uskun, E., Demirci, S., \& Keçeci, D. (2007).Üniversite öğrencilerinde yaşam doyumunu yordayan etkenlerin incelenmesi. Klinik Psikiyatri, 10, 14-27.

Güven, N. (2005). İlişkilerle ilgili bilişsel çarpıtmalar ve evlilikte problem çözme becerilerinin evlilik doyumu ile ilişkisi. M.A.Thesis. Ankara: Ankara University.

Güven, N. \& Sevim, S. (2007). İlişkilerle ilgili bilişsel çarpıtmalar ve algılanan problem çözme becerilerinin evlilik doyumunu yordama gücü. Türk Psikolojik Danışma ve Rehberlik Dergisi, 3(22), 50-61.

Hasta, D. (1996). Ev işi paylaşımı ve ev işi paylaşımında hakkaniyet algısı ile evlilik doyumu ilişkisi. Unpublished M.A.Thesis. Ankara: Ankara University.

Hollist, C.S. \& Miller, R.B. (2005).Family relation: perceptions of attachment style and marital quality in midlife marriage. USA: Blackwell Publishing.

Houseknecht, S. K. \& Macke, A. S. (1981).Combining marriage and career: the marital adjustment of professional women. Journal of Marriage and Family, 43(3), 651-661.

Houseknecht, S. K. (1979). Childlessness and marital adjustment.Journal of Marriage and the Family, 41, 259- 265. http://dx.doi.org/10.1080/1354570 1.2011.582028 accessed on 23.12.2012.

Hünler, O.S. \& Gençöz, T. (2003). Boyuneğici davranışlar ve evlilik doyumu ilişkisi. Türk Psikoloji Dergisi, 18(51), 99-108.

İmamoğlu, O. (2012). Değişen Dünyada Değişen Aile-İçi Roller. Kadın Araştırmaları Dergisi, (1).

Kadılar, E. (2011). Üç kuşak kadının cinsiyet rolleri: Ankara örneği. M.A.Thesis. Adana: Çukurova University.

Kansız, M. \& Arkar, H. (2011).Mizaç ve karakter özelliklerinin evlilik doyumu üzerine etkisi.Anadolu Psikiyatri Dergisi, 12, 24-29.

Kırtıl, S. (2009).Ilköğretim ikinci kademe öğrencilerinin duygusal zeka düzeyleri ile yaşam doyumu düzeylerinin incelenmesi.M.A.Thesis. İzmir: Dokuz Eylül University.

Koydemir, S., Selışık-Sun, Z. E., \& Tezer, E. (2005).Evlilik uyumu ve mükemmelliyetçilik boyutları arasındaki ilişkiler.Türk Psikolojik Danışma ve Rehberlik Dergisi, 3(23), 65-75.

Kulik, L. (1999). Gendered personality disposition and gender role attitudes 
among Israeli students.The Journal of Social Psychology, 139(6), 736-747. http://dx.doi.org/10.1080/00224549909598253 accessed on 18.06.2012.

Lykken, D. \& Tellegen, A. (1996). Happiness is a stochastic phenomenon. Psychological Science, 7, 186-189.

Nehir, S., Çoban, A., Demirci, H., Özbaşaran, F., \& İnceboz, Ü. (2009). Menopozal belirtilerin ve evlilik uyumunun yaşam kalitesi üzerine etkisi. Cumhuriyet Tip Dergisi, 31, 15-21.

Ng, K., Loy, J., Gudmunson, C.G., \& Cheong, W. (2009).Gender differences in marital and life satisfaction among Chinese Malaysians.Sex Roles. 60, 33-43.

Norton, R. (1983). Measuring marital quality: A critical look at the dependent variable.Journal of Marriage and Family, 45, 141-151.

O'Sullivan, S. (2012). 'All changed, changed alterly!? Gender roles attitudes and the feminisation of the Irish labour force. Women's Studies International Forum, 35, 223-232.

Özgür, G., Gümüş-Babacan, A., \& Durdu, B. (2010).Evde ve yurtta kalan üniversite öğrencilerinde yaşam doyumu.Psikiyatri Hemşire Dergisi, 1(1), 25-32.

Özgüven, İ.E. (2001).Ailede iletişim ve yaşam. Ankara: PDREM Yayınları.

Özgüven, İ.E. (2009).Evlilik ve aile terapisi (2.Baskı). Ankara: PDR Yayınları.

Pinsof, W. (2002). The death of "till death us do part": the transformation of pairbonding in the 20th century. Family Process, 41, 135-155.

Polat, D. (2006). Evli bireylerin evlilik uyumları, aldatma eğilimleri ve çatışma eğilimleri arasındaki ilişkilerin bazı değişkenler açısından incelenmesi.M.A.Thesis. Ankara: Ankara University,

Renne, K. S. (1970). Correlates of dissatisfaction in marriage.Journal of Marriage and the Family, 32, 54-66.

Rogers, S.J. \& May, D.C. (2003). Spillover between marital quality and job satisfaction: long-term patterns and gender differences. Journal of Marriage and Family, 65,482-495.

Ryder, R. G. (1973). Longitudinal data relating marriage satisfaction and having a child.Journal of Marriage and the Family, 35, 604-606.

Sekaran, U. (1983). Factors influencing the quality of life in dual-career fami1lies.Journal of Occupational Psychology, 56, 161-174.

Selçukoğlu, Z. (2001). Araştırma görevlilerinde tükenmişlik düzeyi ile yalnızlık düzeyi ve yaşam doyumu arasındaki ilişkinin bazı değişkenler açısından değerlendirilmesi.M.A.Thesis. Konya: Selçuk University.

Spainer, G. B. \& Lewis, R. A. (1980). Marital quality: A review of the seventies. Journal of Marriage and Family, 42, 825-839.

Stevens, D., Kiger, G., \& Riley, P. J. (2001). Working hard and hardly working: domestic labor and marital satisfaction among dual-earner couples. Journal of Marriage and Family, 63(2), 514-526.

Şendil, G., \& Korkut, Y. (2012).Evli çiftlerdeki çift uyumu ve evlilik çatışmasının demografik özellikler açısından incelenmesi.Psikoloji Çalışmaları Dergisi, $28,15-34$.

Şener, A. \& Terzioğlu, G. (2002). Ailede eşler arası uyuma etki eden faktörlerin 
araştırılması. Ankara: Başbakanlık Aile Araştırma Kurumu Başkanlığg.

Tezer, E. (1992). Evlilik doyumu ve iş doyumu: Bir ön çalışma. Psikolojik Danışma ve Rehberlik Dergisi, 1(3), 24-26.

Tezer, E. (1994). Evlilik ve iş doyumu ilişkisi: ikili çatışmalar ve bazı demografik değişkenlerin rolü. Psikolojik Danışma ve Rehberlik Dergisi, 2(1), 1-12.

Tezer, E. (1996). Evlilik ilişkisinden sağlanan doyum: evlilik yaşamı ölçeği. Psikolojik Danışma ve Rehberlik Dergisi, 2(7), 1-7.

Twenge, J. M., Campel, W. K., \& Foster, C. A. (2003). Parenthood and marital satisfaction: A meta analytic review. Journal of Marriage and Family, 65, 574-583.

Ulucan, H., Kılınç, M., Kaya, K. \& Türkçapar, Ü. (2011). Beden eğitimi spor yüksekokullarında öğrenimlerine devam eden öğrencilerin umutsuzluk ve yaşam doyum düzeylerinin incelenmesi. Selçuk Üniversitesi Beden Eğitimi ve Spor Bilim Dergisi, 13(3), 349-356.

Üncü, S. (2007).Duygusal zeka ve evlilik doyumu ilişkisi.M.A.Thesis. Ankara: Ankara University.

West, J. \& Pilgrim, S. (2010). South Asian women in employment: the impact of migration, ethnic origin and the local economy. Journal of Ethnic and Migration tıdies, 21(3), 357-378.

Yetim, Ü. (1993). Life satisfaction: A study based on the organization of personal projects. Social Indicators Research, 29, 277-289.

Yetim, Ü. (2003). The impacts of individualism/collectivism, self-esteem and feeling of mastery on life satisfaction among the Turkish university students and academicians.Social Indicators Research, 61(3), 297-317.

Zeyneloğlu, S. \& Terzioğlu, F. (2011).Toplumsal cinsiyet rolleri tutum ölçeğinin geliştirilmesi ve psikometrik özellikleri.Hacettepe Üniversitesi Eğitim Fakültesi Dergisi, 40, 409-420.

Zeyneloğlu, S. (2008).Ankara'da hemşirelik öğrenimi gören üniversite öğrencilerinin toplumsal cinsiyet rollerine ilişkin tutumları.M.A. dissertation. Ankara: Hacettepe University. http://tuikapp.tuik.gov.tr/adnksdagitapp/ adnks.zul 